\title{
Monoclonal Antibody Therapy
}

National Cancer Institute

\section{Source}

National Cancer Institute. Monoclonal Antibody Therapy. NCI Thesaurus. Code C15490.

The use of monoclonal antibodies in the treatment of any disease or disorder. 